\title{
Phenolic compounds and phenylalanine ammonia lyase activity in two soybean (Glycine max L. cv. Mandarin) cell lines that differ in their ploidy levels
}

KHALEQUZ ZAMAN

Institute of Molecular Biology, Jagiellonian University, Mickiewicza 3, 31-120 Kraków, Poland (Received: August 3, 1987. Revision accepted: September 22, 1987)

\begin{abstract}
Through this preliminary experiment examining different color expressions in two soybean cell lines, $\mathrm{SB}_{1}$ and $\mathrm{SB}_{3}$ several important features were observed. $\mathrm{SB}_{3}$ cells, which produce much more dark brown pigments in both suspension and callus cultures, had higher total phenolics and flavonoid contents as well as higher L-phenylalanine ammonia lyase activity.

Key words: phenolic compound, phenylalanine ammonia lyase, soybean, suspension and callus cultures
\end{abstract}

\section{INTRODUCTION}

Previous studies carried out by Jain and Shargool (1987) on two soybean cell lines, $\mathrm{SB}_{1}$ and $\mathrm{SB}_{3}$, demonstrated that they differ from each other in several ways. $\mathrm{SB}_{3}$ cells grow much slower than $\mathrm{SB}_{1}$ cells in both callus and suspension cultures. Karyotypic analysis revealed that $\mathrm{SB}_{3}$ line is hexaploid whereas the $\mathrm{SB}_{1}$ line is tetraploid (Jain and Shargool 1987, Shargool and Jain 1984, 1986). The two cell lines differ in the fact that $\mathrm{SB}_{3}$ cells produce a large quantity of glutamate dehydrogenase activity during growth on minus nitrate medium, which is not seen in $\mathrm{SB}_{1}$ cells. The most visible difference between $\mathrm{SB}_{1}$ and $\mathrm{SB}_{3}$ cells is observed in their color expression. $\mathrm{SB}_{3}$ cells produce much more dark brown pigments in both cultures and the production of these pigments starts much earlier in the growth cycle.

Phenolic compounds are one of the important secondary metabolites of plants which are involved in color expression (Harborne 1973a, Goodwin and Mercer 1983). Among the plant phenolic compounds, flavonoids form the largest group and main source of pigmentations (Goodwin 1965, Harborne 1973a). 
L-phenylalanine ammonia lyase (PAL) is a key enzyme in the biosynthesis of phenolic compounds. It catalyzes the nonoxidative deamination of L-phenylalanine to trans-cinnamic acid which is precursor for synthesis of phenolic compounds.

It is known that PAL is the rate-limiting enzyme for synthesis of phenolic compounds in tissue culture (Goodwin and Mercer 1983). PAL activity is higher in the $\mathrm{SB}_{3}$ cell lines.

The purpose of this experiment was to examine the levels of phenolic compounds and the PAL activity in $\mathrm{SB}_{1}$ and $\mathrm{SB}_{3}$ cells, which differ in their ploidy levels.

\section{MATERIAL AND METHODS}

Two lines of soybean cells referred to in this report as $\mathrm{SB}_{1}$ and $\mathrm{SB}_{3}$ growing in suspension and callus cultures were kindly provided by Dr. P. Shargool from Saskatechwan University, Saskatoon, Canada.

$\mathrm{SB}_{1}$ cells attain their maximum growth in 4 days while $\mathrm{SB}_{3}$ cells take 6 days to reach that stage (Shargool and Jain 1984, 1986). In this experiment, soybean cells were used after they reached maximum growth in both cultures.

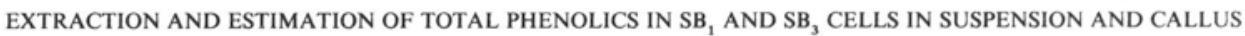
CULTURES

Total phenolics were extracted following the method of Harborne (1973a). Soybean cells after reaching maximum growth in suspension and callus cultures were collected by filtration through miracloth. Five grams of cells were dissolved with $20 \mathrm{~cm}^{3}$ of $2 \mathrm{M} \mathrm{HCl}$ and boiled for $60 \mathrm{~min}$. The extract was then filtered through cotton wool and the volume was made up to $20 \mathrm{~cm}^{3}$ after cooling.

The total phenolic contents in the extract was estimated according to the method of Jennings (1981). One $\mathrm{cm}^{3}$ of extract was treated with $1 \mathrm{~cm}^{3}$ of $1 \mathrm{~N}$ Folin-Ciocalteu reagent and then mixed with $5 \mathrm{~cm}^{3}$ of alkaline reagent $(2 \%$ sodium carbonate in $0.1 \mathrm{~N}$ sodium hydroxide solution) and the solution was mixed well. After $30 \mathrm{~min}$. the absorbance was measured at $760 \mathrm{~nm}$. The same method was also used for callus cultures.

EXTRACTION AND IDENTIFICATION OF FLAVONOIDS IN SB ${ }_{1}$ AND SB ${ }_{3}$ CELLS WITH 95\% ETHANOL

Five grams of cells were dissolved with $10 \mathrm{~cm}^{3}$ of $95 \%$ ethanol and heated under reflux for $10 \mathrm{~min}$. The extract was filtered and centrifuged at $12000 \times \mathrm{g}$ for $5 \mathrm{~min}$. The supernatant was subjected to spectrophotometric analysis by measuring the absorbance at wavelengths ranging from $250 \mathrm{~nm}$ to $610 \mathrm{~nm}$. The same method also used for callus cultured. 
TWO DIMENSIONAL THIN LAYER CHROMATOGRAPHY ON SILICA GEL PLATE FOR SB AND SB $_{3}$ CELL LINES IN SUSPENSION AND CALLUS CULTURES

Five grams of cells were mixed with $10 \mathrm{~cm}^{3}$ of $95 \%$ ethanol and heated under reflux for $10 \mathrm{~min}$. The extract was filtered and centrifuged at $12000 \times \mathrm{g}$ for $10 \mathrm{~min}$. The supernatant was concentrated to dryness. The concentrated supernatant was subjected to two dimensional thin layer chromatography on silica gel plates. The solvent used for developing was butanol:acetic acid:water $(1: 1: 5)$ and aqueous acetic acid.

After development the spots were located under UV light with additional fuming of the chromatogram with ammonia vapors. Each group of spots was removed from the plate and the compounds were extracted by suspending the gel in $3 \mathrm{~cm}^{3}$ of water. The suspension was spectrophometric analysis by measuring the absorbance at wavelengths ranging from $250 \mathrm{~nm}$ to $610 \mathrm{~nm}$.

MEASUREMENT OF L-PHENYLALANINE AMMONIA LYASE ACTIVITY

Acetone powder was prepared following the method of $\mathrm{Jain}$ and U1la h (1979). Both $\mathrm{SB}_{1}$ and $\mathrm{SB}_{3}$ cells after reaching the maximum growth in suspension cultures were collected by filtration through miracloth. Forty grams of cells were homogenized in $150 \mathrm{~cm}^{3}$ of chilled acetone for $2 \mathrm{~min}$. by using a virtis homogenizer at speed 70 . The homogenate was filtered through filter paper and the residue was washed three times with $30 \mathrm{~cm}^{3}$ of cold acetone. The residue was dried between several layers of filter paper and finally in a vacuum dessicator until all the acetone was evaporated off. The dried powder was stored at $4^{\circ} \mathrm{C}$ in a tightly sealed container.

ENZYME ASSAY

PAL activity of the acetone powder was determined by the method of $\mathrm{Harborne}(1973 \mathrm{~b})$. The reaction mixture contained $0.2 \mathrm{~g}$ of acetone powder and $4 \mathrm{~cm}^{3}$ of $0.1 \%$ L-phenylalanine solution in $0.1 \mathrm{M}$ borate buffer at $\mathrm{pH} 8.8$. The blank and reaction mixtures were incubated at $37^{\circ} \mathrm{C}$ for 2 hours, after which the reaction was arrested with $0.5 \mathrm{~cm}^{3}$ of $2 \mathrm{M} \mathrm{HCl}, 7 \mathrm{~cm}^{3}$ of water was added to the blank and the reaction acidified by using $\mathrm{HCl}$ to $\mathrm{pH} 5$ and the reaction product was extrated three times with $5 \mathrm{~cm}^{3}$ of ether. The ether extract was evaporated to dryness using a vacuum evaporator. The dried residue was dissolved in $3 \mathrm{~cm}^{3}$ of ethanol. The optical density was measured at $273 \mathrm{~nm}$ with an ethanol blank.

The concentration of cinnamic acid was calculated from its molar extinction coefficient of 20.400. One unit of specific activity of PAL is expressed as formation of $1 \mu$ mole transcinnamic acid per minute per mg protein of acetone powder at $37^{\circ} \mathrm{C}$. 
The method used for the estimation of protein in acetone powder was similar to that of $\mathrm{Bradford}$ (1976). Acetone powder, $0.2 \mathrm{~g}$ was dissolved in $0.15 \mathrm{M} \mathrm{NaCl}$ and the volume made up to $10 \mathrm{~cm}^{3}, 0.1 \mathrm{~cm}^{3}$ of this solution was mixed with $5 \mathrm{~cm}^{3}$ of protein reagent. After $15 \mathrm{~min}$. the absorbance was measured at $595 \mathrm{~nm}$ and the amount of protein was determined from a standard curve by using the same method with bovine serum albumin as a standard.

\section{RESULTS}

The level of total phenolic compounds in $\mathrm{SB}_{1}$ and $\mathrm{SB}_{3}$ cells is represented in Table 1. A comparison of the two cell lines indicates that the level of phenolic compounds in $\mathrm{SB}_{3}$ cells was 1.4 times higher in suspension culture and 1.8 times higher in callus cultures than in $\mathrm{SB}_{1}$ cell lines. Flavonoid extracts of $\mathrm{SB}_{1}$ and $\mathrm{SB}_{3}$ cells were scanned by measuring the absorbance at wavelengths ranging from $250 \mathrm{~nm}$ to $610 \mathrm{~nm}$. The flavonoids were indentified on the basis of comparison with standard substances, characteristic colors and $R_{f}$ coefficients (Harborne 1959, 1973a).

Table 1

Level of total phenolic compounds in $\mathrm{SB}_{1}$ and $\mathrm{SB}_{3}$ cell lines ${ }^{\mathrm{a}}$

\begin{tabular}{|c|c|c|}
\hline \multirow{2}{*}{ Cell lines } & \multicolumn{2}{|c|}{ Optical density at $760 \mathrm{~nm}^{\mathrm{b}}$} \\
\cline { 2 - 3 } & suspension culture & callus cultures \\
\hline $\mathrm{SB}_{1}$ & 0.189 & 0.381 \\
$\mathrm{SB}_{3}$ & 0.278 & 0.690 \\
\hline
\end{tabular}
culture.

- $\mathrm{SB}_{1}$ and $\mathrm{SB}_{3}$ cells were 28-days-old in suspension culture and 65-days-old in callus

${ }^{b}$ The levels of total phenolic compounds in $\mathrm{SB}_{1}$ and $\mathrm{SB}_{3}$ cells are expressed in terms of optical density at $760 \mathrm{~nm}$ after developing color with the Folin-Ciocalteu reagent.

Both $\mathrm{SB}_{1}$ and $\mathrm{SB}_{3}$ cells showed a maximum absorption at $250 \mathrm{~nm}$ (Harborne 1973a) and the absorbance decreased with increased wavelengths (Figs. 1A, B). This results indicates that isoflavone, flavone, biflavonyl which show absorption maximums between $250 \mathrm{~nm}$ and $270 \mathrm{~nm}$ were the most abundant classes of flavonoids in both cells (Jain and Shargool 1987). Flavanone, flavan-3-ol and flavanonol which have absorption maximums at wavelengths between $270 \mathrm{~nm}$ and $310 \mathrm{~nm}$ (Harborne 1973a) were the second in abundance.

Other classes of flavonoids such as chalcone and flavonal, absorption maximums $350 \mathrm{~nm}$ to $390 \mathrm{~nm}$ (Harborne 1973a), aurones absorption maximums of $390 \mathrm{~nm}$ to $430 \mathrm{~nm}$ (Harborne 1973a), and anthocyanine with an absorption maximums of $475 \mathrm{~nm}$ to $560 \mathrm{~nm}$ (Harborne 1973a) were 

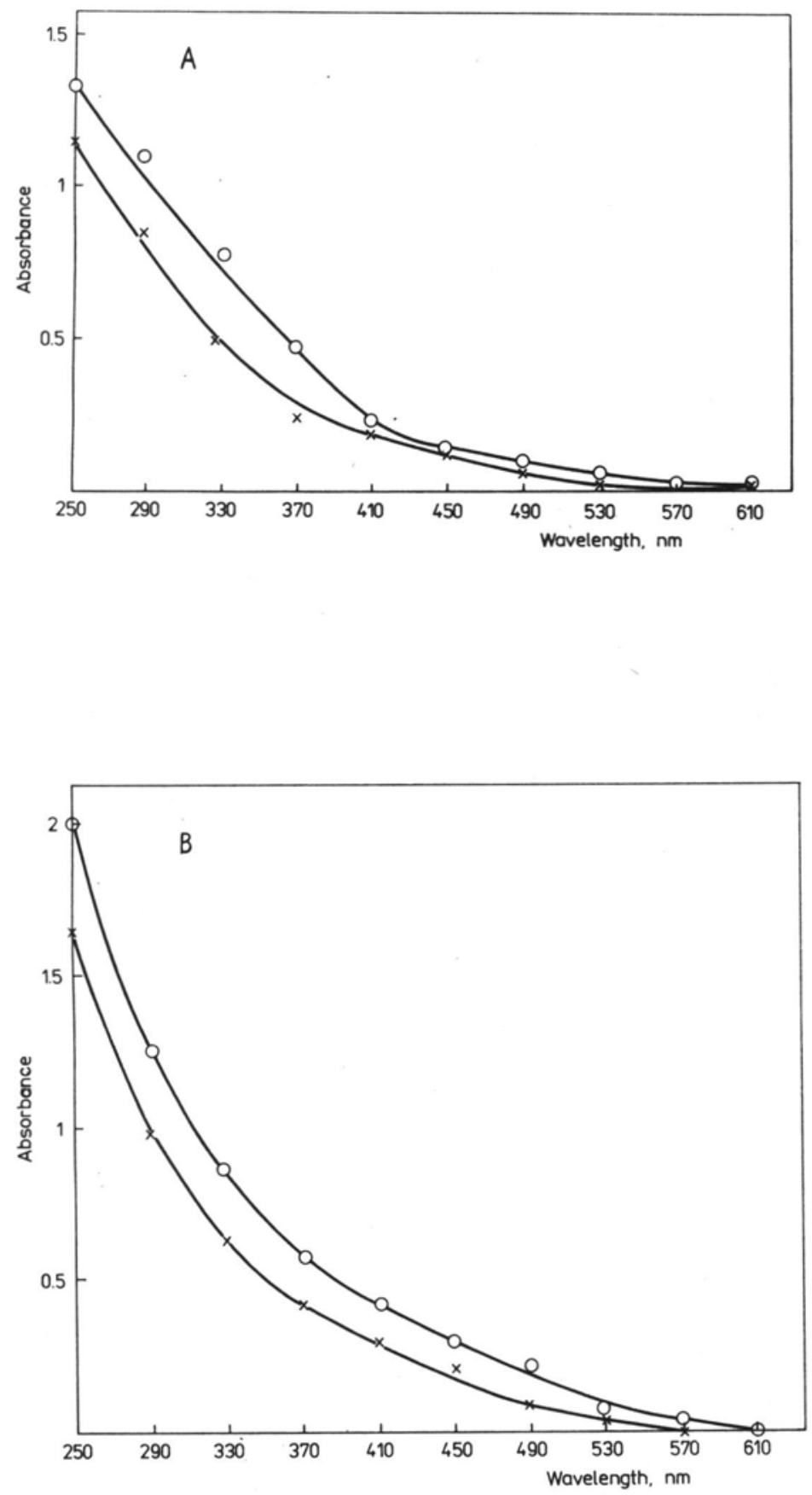

Fig. 1. Measurement of absorbance at wavelenghts ranging from $250 \mathrm{~nm}$ to $610 \mathrm{~nm}$ for $95 \%$ ethanol extract of flavonoids from $\mathrm{SB}_{1}$ and $\mathrm{SB}_{3}$ cell lines. $\mathrm{A}$ - suspension culture, $\mathrm{B}$ - callus culture, $\mathrm{O}-\mathrm{SB}_{3}$ cell line, $\mathrm{X}-\mathrm{SB}_{1}$ cell line 


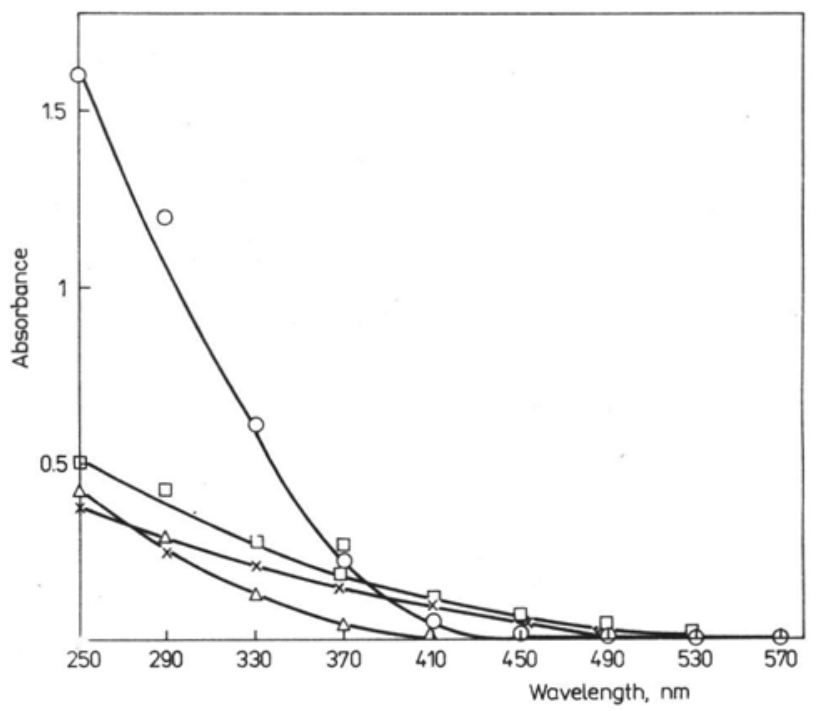

Fig. 2. Measurement of absorbance at wavelengths ranging from $250 \mathrm{~nm}$ to $610 \mathrm{~nm}$ for separated spots on a two dimensional chromatogram of $95 \%$ ethanol extract of flavonoids from $\mathrm{SB}_{1}$ cell line in suspension culture: $\mathrm{X} \longrightarrow \mathrm{X}-\operatorname{spot} 1, \boldsymbol{\Delta}-\boldsymbol{\Delta}-\operatorname{spot} 2, \square-\square-\operatorname{spot} 3$, $\mathrm{O}-\mathrm{O}-\operatorname{spot} 4$

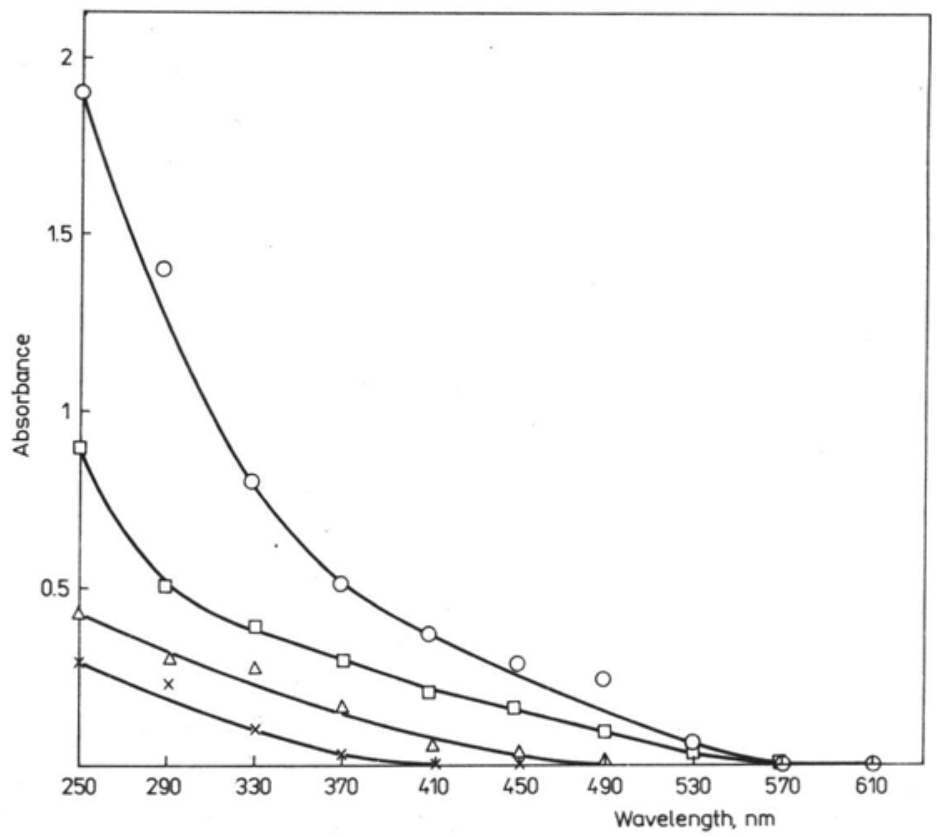

Fig. 3. Measurement of absorbance at wavelenghts ranging from $250 \mathrm{~nm}$ to $610 \mathrm{~nm}$ for separated spots on a two dimensional chromatogram of $95 \%$ ethanol extract of flavonoids from $\mathrm{SB}_{3}$ cell line in suspension culture: $\mathrm{X} \longrightarrow \mathrm{X}-\operatorname{spot} 1, \boldsymbol{\Delta}-\boldsymbol{\Delta}-\operatorname{spot} 2, \square-\square-\operatorname{spot} 3$, $\mathrm{O} \quad \mathrm{O}-\operatorname{spot} 4$ 


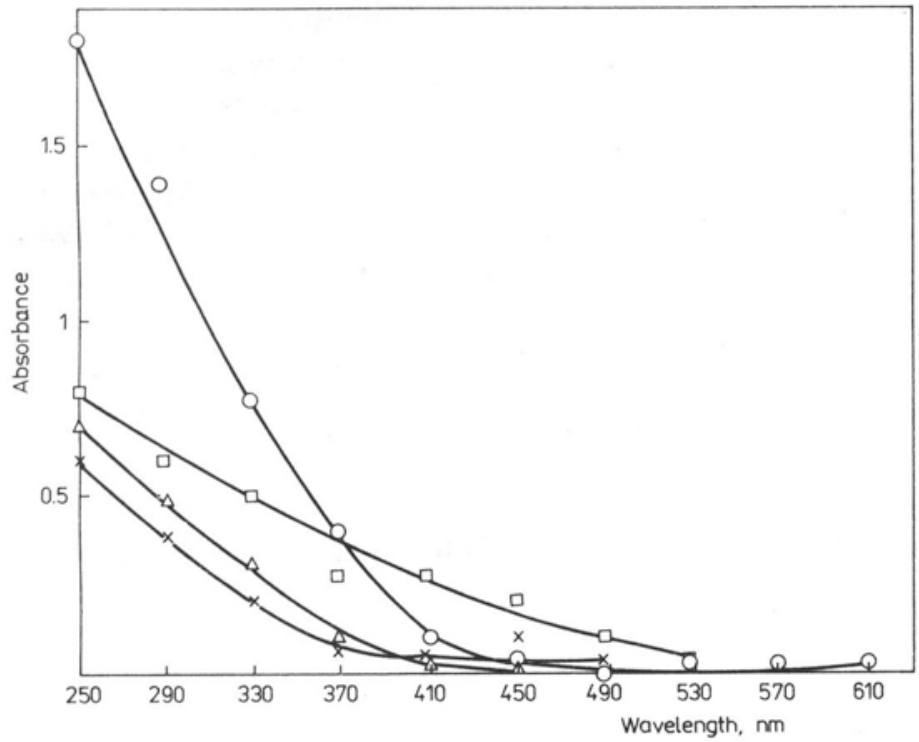

Fig. 4. Measurement of absorbance at wavelengths ranging from $250 \mathrm{~nm}$ to $610 \mathrm{~nm}$ for separated spots on a two dimensional chromatogram of $95 \%$ ethanol extract of flavonoids from $\mathrm{SB}_{1}$ cell line in callus culture: $\mathrm{X}-\mathrm{X}-\operatorname{spot} 1, \boldsymbol{\Delta}-\boldsymbol{\Delta}-\operatorname{spot} 2, \square-\square-\operatorname{spot} 3$, $\mathrm{O} \quad \mathrm{O}-\operatorname{spot} 4$

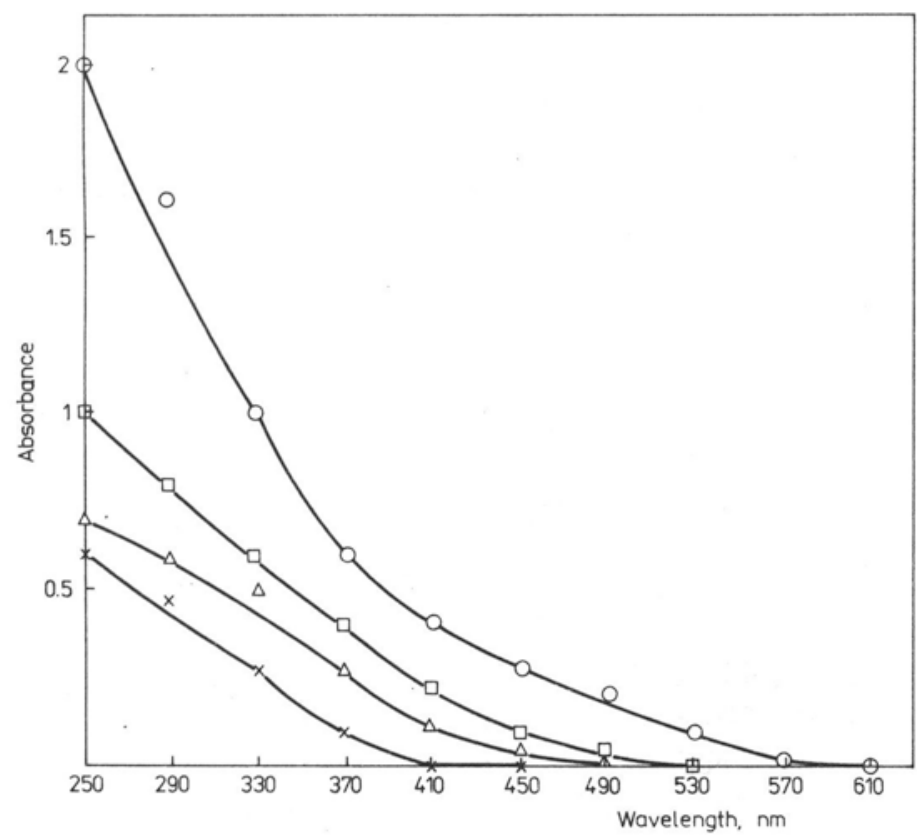

Fig. 5. Measurement of absorbance at wavelengths ranging from $250 \mathrm{~nm}$ to $610 \mathrm{~nm}$ for separated spots on a two dimensional chromatogram of $95 \%$ ethanol extract of flavonoids from $\mathrm{SB}_{3}$ cell line in callus culture: $\mathrm{X} \longrightarrow \mathrm{X}-\operatorname{spot} 1, \boldsymbol{O}-\boldsymbol{\Delta}-\operatorname{spot} 2, \square-\mathrm{O}-\operatorname{spot} 3$, $\mathrm{O} \quad \mathrm{O}-\operatorname{spot} 4$ 
present in both cell lines either in little or negligible quantities. Comparison of the two cell lines showed $\mathrm{SB}_{3}$ to be richer in flavonoids (Figs. 1A, B).

Further analysis of the concentrated flavonoids extract by two dimensional chromatography on silica gel confirmed these preliminary results. There were four groups of spots on the chromatograms of $\mathrm{SB}_{1}$ and $\mathrm{SB}_{3}$ cells, respectively (Figs. 2, 3, 4, 5). Each group of spots was removed separately from the plate and indentified by measuring the absorbance at wavelengths ranging from 250 $\mathrm{nm}$ to $610 \mathrm{~nm}$. The majority of flavonoids were located at spot 4 in both cell lines. Other spots were shown to contain an insignificant amount of flavonoids. In spot 4, the main classes of flavonoids were isoflavone, flavone and biflavonyl. On comparison, $\mathrm{SB}_{3}$ was seen to be richer in flavonoids (Figs. 4, 5).

The major classes of flavonoids that contributed to the differences between the lines were almost the same as shown in Fig. 1, except for the isoflavone and anthocyanins. This again confirms the results shown in Fig. 1, but the significance of isoflavone and anthocyanins in their difference was not shown in Fig. 1.

The most notable observation from Figs. 1, 4, 5 is that $\mathrm{SB}_{3}$ cells are richer in flavonoids. Also, some classes of flavonoids such as flavanone and flavan-3-ols which are susceptible to oxidation and polymerizations are present in greater quantities in $\mathrm{SB}_{3}$ cells.

\section{DISCUSSION}

The purpose of this experiment was to examine the levels of phenolic compounds and the PAL activity in $\mathrm{SB}_{1}$ and $\mathrm{SB}_{3}$ cells, which differ in their ploidy levels. The $\mathrm{SB}_{3}$ cell line is a hexaploid and produces much more dark brown pigments in both suspension and callus cultures ( $\mathrm{J}$ ain and $\mathrm{Sh}$ a rgool 1987, Shargool and Jain 1984, 1986).

It was shown in this study that $\mathrm{SB}_{3}$ cells had a higher total phenolics content (Table 1). This observation is significant in that phenolic compounds are one of the important secondary metabolites of plants involved in coloration (Goodwin and Mercer 1983). This finding leads us to the idea that some substances causing different colorations in two soybean cell lines are phenolic compounds.

Flavonoids are not directly involved in brown pigmentation in plants. Most of the brown pigments produced from flavonoids appear to be formed by the oxidation of flavonoids such as catechins, flavanones, 3-hydroxy-flavanones Siegelman 1955, Goodwin 1965). In general, flavone and 3-hydroxy-flavanones are not directly involved in coloration but they are very susceptible to oxidation and yield brown pigments in plant tissues.

Flavan-3-ols and flavan-3,4-diols are largely involved in polymerization to form oligomers and polymers and yield brown pigments. In some cases, 
browning is caused when flavonoids chelate with metal ions (Goodwin 1965). Based on the observations it can be suggested that the $\mathrm{SB}_{3}$ cell line is more likely to undergo modification of flavonoids through polymerization, oxidation and chelation. This may lead to the production of much more brown pigments in $\mathrm{SB}_{3}$ cells.

L-phenylalanine ammonia lyase is a key enzyme in the biosynthesis of phenolic compounds. It catalyzes the non-oxidative deamination of L-phenylalanine to trans-cinnamic acid (Loomis and Battaile 1966, Goodwin and Mercer 1983).

In dicotyledonous plants it appears to be the sole link between the shikimic acid pathway and pathways leading to cuumarins, flavonoids, condensed tannins and lignins (Maier and $\mathrm{H}$ a segaw a 1970). Concomitant increases in levels of PAL and phenolic compounds have been demonstrated in may plant tissues and tissue cultures (Camm and Towers 1973).

There is a direct relationship between PAL activity and the rate of naringenin glycoside (flavanone glycoside) accumulation in developing grapefruits (Maier and Hasegawa 1970). Flavonoid glycoside was accumulated with increased PAL activity in parsley culture (Hahlbrock et al. 1976), Lawton et al. (1983) observed that induction of PAL activity be elicitor in fresh been resulted in the accumulation of phytoalexin which is one of the phenolic compounds. In addition there are many examples of correlation between increased production of phenolic compounds and increases in PAL activity (Camm and Towers 1973). Because $\mathrm{SB}_{3}$ cell lines showed higher levels of total phenolic compounds, flavonoids, tannins and PAL activity were expected to be higher in the $\mathrm{SB}_{3}$ cell lines. The result shows that this was indeed the case. PAL activity was approximately three times higher in the $\mathrm{SB}_{3}$ cell lines (Table 2).

Table 2

Specific activity of PAL in the acetone powders prepared from $\mathrm{SB}_{1}$ and $\mathrm{SB}_{3}$ cells

\begin{tabular}{|c|c|}
\hline Cell lines & $\begin{array}{c}\text { Specific activity } \\
\left(\mu \text { mole } \min ^{-1} \mathrm{mg}^{-} \text {protein }\right.\end{array}$ \\
\hline $\begin{array}{l}\mathrm{SB}_{1} \\
\mathrm{SB}_{3}\end{array}$ & $\begin{array}{l}2.89 \\
7.94\end{array}$ \\
\hline
\end{tabular}

However, total phenolic content was also higher. This indicates that biosynthesis of different groups of phenolic compounds is not regulated by PAL activity. The result of PAL activity implicates it as a regulatory system for the synthesis of phenolic compounds but further research is warranted on its specific role. 


\section{REFERENCES}

Bradford M. M., 1976. A rapid and sensitive method for the quantitation of microgram quantities of protein utilizing the principle of protein-dye binding. Anal. Biochem. 72: 248-254.

Camm E. L., Towers G. H. N., 1973. Review article. L-phenylalanine ammonia lyase. Phytochemistry 12: 961-973.

Goodwin T. W., 1965. Nature and properties of flavonoids. In: Chemistry and Biochemistry of plant pigments. Academic Press, London, pp. 211-242.

Goodwin T. W., Mercer E. I., 1983. Plant phenolics. In: Introduction of plant biochemistry. (2nd ed.), Pergamon Press, Oxford.

Hahlbrock K. et al., 1976. Coordinated induction and subsequent activity changes of two groups of metabolically interrelated enzyme-light induced synthesis of flavonoid glycosides in cell suspension cultures of Petroselium hortense. Eur. J. Biochem. 61: 199-206.

Harborne J. B., 1959. The chromatography of the flavonoid pigments. J. Chromatogr. 2: 581-603.

Harborne J. B., 1973a. Phenolic compounds. In: Phytochemical methods. Chapman and Hall, London, pp. 33-44, 52-59.

Harborne J. B., 1973b. Isolation of plant enzyme phenylalanine ammonia lyase. In: Phytochemical methods. Chapman and Hall, London, pp. 254-255.

Jain J. C., U11ah M. R., 1979. L-phenylalanine ammonia lyase in tea leaf. Two and A bud. (India) 26: 67-69.

Jain J. C., Shargool P. D., 1987. An examination of the growth rates of two soybean cell lines that differ in their ploidy levels. J. Plant Physiol. 130: 137-146.

Jennings A. C., 1981. The determination of dihydroxy phenolic compounds in extracts of plant tissues. Anal. Biochem. 188: 396-398.

Lawton M. A., Dixon R. A., Hahlbrock K., Lamb C., 1983. Rapid induction of the synthesis of phenylalanine ammonia lyase and of chalcone synthase in elicitor-treated plant cells. Eur. J. Biochem. 129: 593-601.

Loomis W. D., Battaile J., 1966. Plant phenolic compounds and the isolation of plant enzymes. Phytochemistry 5: 423-438.

Maier V. P., Hasegawa S., 1970. L-phenylalanine ammonia lyase activity and naringenin glycoside accumulation in developing grapefruit. Phytochemistry 9: 139-144.

Shargool P. D., Jain J. C., 1984. The effect of growth in high concentration of ammonia on enzymes involved in ammonia assimilation in soybean cells of differing ploidy. Proc. Int. Assoc. Plant Tiss. Cult. Symp. held at Saskatoon, Saskatechwan, Canada. pp. 48.

Shargool P. D., Jain J. C., 1986. Growth responses of clonal variants of soybean cells. Proc. Fed. Biol. Soc. Symp. held at Saskatoon, Saskatechawan, Canada. pp. 157.

Siegerman H. W., 1955. Detection and indentification of polyphenoloxidase substrates in apple and pear skins. Arch. Biochem. Biophys. 56: 97-102.

Badanie zwiazków fenolowych $i$ aktywności liazy fenyloalaninowej $w$ dwóch liniach komórek soi (Glycine max L. cv. Mandarin) różniących się ploidalnościa

\section{Streszczenie}

Podczas wstępnych doświadczeń mających na celu zbadanie różnych zabarwień w dwóch liniach komórek soi $\mathrm{SB}_{1}$ i $\mathrm{SB}_{3}$ zaobserwowano kilka ważnych cech. Komórki $\mathrm{SB}_{3}$ które wytwarzają więcej ciemnobrązowych pigmentów zarówno w kulturach zawiesinowych, jak i kallusowych charakteryzowały się większą zawartością związków fenolowych i flawonoidów. Także aktywność liazy fenyloalaninowej była większa w komórkach $\mathrm{SB}_{3}$. Aby odkryć dokładny mechanizm wytwarzania większej ilości brązowych pigmentów w komórkach $\mathrm{SB}_{3}$ należałoby podjąć dalsze badania. Pożyteczne byłoby także zbadanie oksydazy polifenolowej. 